\title{
KAJIAN STRUKTUR SUPERBIMATRIKS
}

\author{
${ }^{1}$ Henry W. M. Patty, ${ }^{2}$ Chevano Bill Pattipeilohy, ${ }^{3}$ A. Z. Wattimena \\ 1,2,3 Jurusan Matematika FMIPA, Universitas Pattimura \\ Jl. Ir. M. Putuhena, Kampus Unpatti, Poka-Ambon, Indonesia \\ e-mail: ${ }^{1}$ henrywmpatty81@gmail.com
}

\begin{abstract}
Abstrak
dimana $A_{1} \neq A_{2}$ maka $A_{1} \cup A_{2}$ merupakan superbimatriks. Dengan kata lain perpaduan antara dua himpunan supermatriks disebut sebagai superbimatriks. Diberikan beberapa definisi superbimatriks antara lain yaitu superbimatriks baris dan kolom, superbimatriks persegi dan persegi panjang, semi superbimatriks, quasi superbimatriks, transpose superbimatriks, serta superbimatriks simetri dan diperoleh suatu sifat bahwa jika $A=A_{1} \cup A_{2}$ yang merupakan superbivektor kolom maka $A A^{T}$ merupakan superbimatriks simetri.
\end{abstract}

Kata Kunci: bimatriks, gabungan, matriks, superbimatriks, supermatriks

\section{STUDY OF SUPERBIMATRICES STRUCTURE}

\begin{abstract}
This research its developed to study the structure of superbimatrix which if $\boldsymbol{A}_{\mathbf{1}}$ and $\boldsymbol{A}_{\mathbf{2}}$ is supermatriks where $\boldsymbol{A}_{1} \neq \boldsymbol{A}_{2}$ then $\boldsymbol{A}_{\mathbf{1}} \cup \boldsymbol{A}_{\mathbf{2}}$ be a superbimatrix. In another words toward to the union of two supermatrix set is called as superbimatrix. Let definitions of superbimatrices such that row and column superbimatrix, mixed superbimatrix, square and rectangular superbimatrix, semi superbimatrix, quasy superbimatrix, transpose superbimatrix and simetris superbimatris that found a charactheristic that if $A=A_{1} \cup A_{2}$ is column superbimatrix then $A A^{T}$ simetris superbimatrix.
\end{abstract}

Keywords: bimatrix, matrix, superbimatrix, supermatrix, union

\section{Pendahuluan}

Matriks merupakan alat yang ampuh untuk menyelesaikan masalah yang ditemukan dalam banyak aspek kehidupan dengan cara mengubah masalah-masalah tersebut dalam bentuk model linear. Model linear yang dijumpai bukan saja dalam bentuk suatu persamaan tetapi dapat direpresentasikan dalam sistem persamaan linear. Sehingga untuk memudahkan penyelesaian sistem persamaan linear tersebut dapat digunakan matriks. Walaupun teori matriks merupakan ilmu yang sudah ditemukan sejak tahun 1859 oleh Arthur Cayley (1821-1895), namun beberapa ilmuwan sebelum Cayley sudah memotivasi penggunaan matriks dalam penyelesaian model-model linear seperti Takakazu Zeki (1642-1708) dan Piere Frederic Sarrus (1798-1861). Dalam perkembangannya teori matriks bermanfaat dalam menyelesaikan masalah input-output dalam ekonomi yang mengandung banyak variabel ataupun dalam analisis sistem informasi. Namun masalah riil yang muncul jika disajikan dalam bentuk matriks akan terbatas pada dimensi matriksnya sehingga generalisasi matriks dalam bentuk supermatriks dapat menjadi suatu solusinya. Supermatriks didefinisikan sebagai suatu matriks dengan elemen-elemennya berupa skalar-skalar atau matriks-matriks (Kandasamy dan Smarandache, 2008). Dalam aljabar linear supermatriks dikenal dengan matriks blok yang elemen-elemenya merupakan submatriks.

Konsep supermatriks dimotivasi dari matriks partisi yang merupakan pengelompakan matriksmatriks dalam ukuran tertentu dari suatu matriks sederhana berukuran $n \times n$. Berbeda dengan matriks partisi, supermatriks merupakan kumpulan elemen-elemen yang merupakan matriks sederhana dan skalarskalar yang disusun menurut aturan baris dan kolom sehingga menjadi matriks baru yang berpartisi. Dimana operasi penjumlahan, pengurangan, pergandaan, determinan dan invers matriks dapat dioperasikan pada sebarang matriks konvesional menurut aturan tertentu. Namun pada operasi penggabungan matriks 
dikondisikan untuk matriks-matriks tidak biasa (supermatriks) yang berbeda ukuran, Konsep ini dinamakan superbimatriks. Sehingga dapat dikatakan bahwa superbimatriks merupakan gabungan atau kumpulan atau perpaduan dari supermatriks. Berdasarkan uraian di atas maka struktur superbimatriks yang meliputi bentuk dan operasinya perlu diperkenalkan untuk menjawab permasalahan lain yang muncul yang tidak dapat terselesaikan dengan matriks sederhana.

\section{Landasan Teori}

Teori bimatriks pertama kali diperkenalkan oleh W. B. Vasantha Kandasamy dan Florentin Smarandache (2009) dalam buku yang berjudul "bimatrices" dan pada tahun yang sama Kandasamy dan Smarandache kembali memperkenalkan teori superbimatriks dalam buku "superbimatrices and their generalizations”. Dalam buku tersebut dibahas definisi bimatriks dan definisi superbimatriks serta sifatsifatnya yang sangat berbeda dengan definisi dan sifat-sifat matriks yang konvensional. Superbimatriks menjadi topik menarik yang di bahas pada satu dekade terakhir dengan pembahasan yang terstruktur. Karena dimulai dari bentuk matriks yang sederhana yang mana unsur-unsur atau elemen-elemennya terdiri dari angka biasa atau skalar, hal ini berarti, superbimatriks memiliki struktur tertentu yang dapat dibentuk. Pembahasan tentang dasar-dasar matriks seperti matriks diagonal, matriks identitas, matriks segitiga atas dan bawah serta matriks simetri mengacu pada buku Howard Anton jilid 1 (2000). Pada bagian ini akan disajikan mengenai landasan teori terkait dengan pembahasan superbimatriks yaitu bimatriks dan superbimatriks berupa definisi dan cara pembentukan supermatriks.

Definisi 2.1 [7] Suatu bimatriks $A_{B}$ didefinisikan sebagai perpaduan (gabungan) dari dua matriks persegi panjang $A_{1}$ dan $A_{2}$ yang tersusun dalam baris dan kolom yang ditulis sebagai : $A_{B}=A_{1} \cup A_{2}$ dimana $A_{1} \neq A_{2}$ dengan;

$A_{1}=\left[\begin{array}{cccc}a_{11}^{1} & a_{12}^{1} & \cdots & a_{1 n}^{1} \\ a_{21}^{1} & a_{22}^{1} & \cdots & a_{2 n}^{1} \\ \vdots & \vdots & \cdots & \vdots \\ a_{m 1}^{1} & a_{m 2}^{1} & \cdots & a_{m n}^{1}\end{array}\right] \quad$ dan $\quad A_{2}=\left[\begin{array}{cccc}a_{11}^{2} & a_{12}^{2} & \cdots & a_{1 n}^{2} \\ a_{21}^{2} & a_{22}^{2} & \cdots & a_{2 n}^{2} \\ \vdots & \vdots & \cdots & \vdots \\ a_{m 1}^{2} & a_{m 2}^{2} & \cdots & a_{m n}^{2}\end{array}\right]$ Jadi

$$
A_{B}=A_{1} \cup A_{2}=\left[\begin{array}{cccc}
a_{11}^{1} & a_{12}^{1} & \cdots & a_{1 n}^{1} \\
a_{21}^{1} & a_{22}^{1} & \cdots & a_{2 n}^{1} \\
\vdots & \vdots & \cdots & \vdots \\
a_{m 1}^{1} & a_{m 2}^{1} & \cdots & a_{m n}^{1}
\end{array}\right] \cup\left[\begin{array}{cccc}
a_{11}^{2} & a_{12}^{2} & \cdots & a_{1 n}^{2} \\
a_{21}^{2} & a_{22}^{2} & \cdots & a_{2 n}^{2} \\
\vdots & \vdots & \cdots & \vdots \\
a_{m 1}^{2} & a_{m 2}^{2} & \cdots & a_{m n}^{2}
\end{array}\right]
$$

Simbol ' $U$ ' hanya sebatas notasi saja

Jika $A_{1}=A_{2}$ maka $A_{B}=A_{1} \cup A_{2}$ bukanlah suatu bimatriks. Suatu bimatriks $A_{B}$ dinotasikan dengan $\left(a_{i j}^{1}\right) \cup\left(a_{i j}^{2}\right)$. jika kedua matriks $A_{1}$ dan $A_{2}$ adalah matriks $m \times n$ maka bimatriks $A_{B}$ dinamakan bimatriks persegi panjang $m \times n$. Selanjutnya dibuat suatu asumsi matriks nol adalah gabungan dari 2 matriks nol walaupun jika $A_{1}$ dan $A_{2}$ sama sehingga $A_{1}=A_{2}=\{0\}$. Selain bimatriks persegi panjang didefinisikan juga suatu bimatriks persegi dan bimatriks campuran sebagai berikut:

Definisi 2.2 [7] Diberikan $A_{B}=A_{1} \cup A_{2}$. Suatu bimatriks $A_{B}$ dinamakan bimatriks persegi jika masingmasimg matriks $A_{1}$ dan $A_{2}$ adalah matriks persegi. Jika salah satu dari matriks dalam bimatriks $A_{B}=A_{1} \cup A_{2}$ merupakan matriks persegi dan yang lainnya adalah matriks persegi panjang atau jika keduanya yaitu $A_{1}$ dan $A_{2}$ merupakan matriks persegi panjang katakanlah $m_{1} \times n_{1}$ dan $m_{2} \times n_{2}$ dengan $m_{1} \neq m_{2}$ atau $n_{1} \neq n_{2}$ maka dapat dikatakan $A_{B}$ adalah bimatriks campuran.

Selain pengertian dasar bimatriks, berikut diberikan konsep supermatriks. Suatu supermatriks merupakan matriks yang elemen-elemennya berupa skalar-skalar atau matriks-matriks.

Sebagai ilustrasi: $a_{11}=\left[\begin{array}{cc}2 & -4 \\ 0 & 1\end{array}\right], a_{12}=\left[\begin{array}{cc}0 & 40 \\ 21 & -12\end{array}\right], a_{21}=\left[\begin{array}{cc}1 & -1 \\ 5 & 7 \\ -2 & 9\end{array}\right]$, dan $a_{22}=\left[\begin{array}{cc}4 & 12 \\ -17 & 5 \\ 3 & 11\end{array}\right]$ 
dengan asumsi $a_{i j}, 1 \leq \mathrm{i}, \mathrm{j} \leq 2$, menotasikan matriks, bukan skalar suatu matriks.

Jika ke-empat matriks disusun dalam matriks berikut :

$$
A=\left[\begin{array}{ll}
a_{11} & a_{12} \\
a_{21} & a_{22}
\end{array}\right] \text { atau secara lengkap ditulis sebagai } \quad \mathrm{A}=\left[\begin{array}{cc|cc}
2 & -4 & 0 & 40 \\
0 & 1 & 21 & -12 \\
\hline 3 & -1 & 4 & 12 \\
5 & 7 & -17 & 6 \\
2 & 9 & 3 & 11
\end{array}\right]
$$

maka A disebut supermatriks. Hal ini menyebabkan supermatriks kadang disebut matriks blok.

Untuk membentuk supermatriks dapat mengacu pada Supermatrix models (Yost, 1991)

\section{Hasil dan Pembahasan}

Pada bagian ini akan dibahas tentang gagasan dari superbimatriks dan akan dijelaskan beberapa sifatnya. Setiap definisi-definisi dan tipe dari superbimatriks diberikan sambil tetap mengacu pada definisi dan tipe pada matriks sederhana. Pada bagian 2, telah dibahas pengertian dari supermatriks, selanjutnya diberikan pengertian superbimatriks yang merupakan gabungan dua supermatriks.

Definisi 3.1 [8] Diberikan $A_{1}$ dan $A_{2}$ sebarang dua supermatriks, A disebut superbimatriks jika $A_{B}=A_{1} \cup A_{2}$

Lebih lanjut, jika $A_{1}=A_{2}$ sebagai matriks partisi maka $A_{1}$ dan $A_{2}$ haruslah memiliki partisi yang berbeda. Jika $A_{1}=A_{2}$ dan $A_{1}, A_{2}$ memiliki himpunan partisi yang sama maka $A_{B}=A_{1} \cup A_{2}$ bukan superbimatriks. Lebih jelasnya dapat dilihat pada contoh berikut ini

Contoh 3.2 Diberikan matriks ;

$$
A_{1}=\left[\begin{array}{cc|cc}
3 & 1 & 0 & 2 \\
1 & 1 & 6 & 0 \\
0 & 1 & 0 & -1
\end{array}\right], \quad A_{2}=\left[\begin{array}{lllll}
1 & 1 & 0 & 1 & 0 \\
2 & 0 & 2 & 0 & 1 \\
\hline 5 & 2 & 1 & 0 & 5 \\
1 & 1 & 0 & 1 & 2
\end{array}\right], A_{3}=\left[\begin{array}{cc|cc}
3 & 1 & 0 & 2 \\
1 & 1 & 6 & 0 \\
0 & 1 & 0 & -1
\end{array}\right]
$$

$A_{1}, A_{2}, A_{3}$ adalah dua supermatriks sehingga $A=A_{1} \cup A_{2}$ itu adalah superbimatriks, namun $A=A_{1} \cup A_{3}$ bukan superbimatriks karena $A_{1}=A_{3}$. Jadi, $A=\left[\begin{array}{cc|cc}3 & 1 & 0 & 2 \\ 1 & 1 & 6 & 0 \\ 0 & 1 & 0 & -1\end{array}\right] \cup\left[\begin{array}{ccccc}1 & 1 & 0 & 1 & 0 \\ 2 & 0 & 2 & 0 & 1 \\ \hline 5 & 2 & 1 & 0 & 5 \\ 1 & 1 & 0 & 1 & 2\end{array}\right]$

Sama hal dengan matriks baris dan matriks kolom pada matriks sederhana selanjutnya akan didefenisikan superbimatriks baris dan kolom sebagai berikut.

Definisi 3.3 [8] Diberikan $A_{B}=A_{1} \cup A_{2}$ dengan $A_{1}=\left[a_{11}\left|a_{12}\right| \ldots \mid a_{1 n}\right]$ dan $A_{2}=$ $\left[a_{21}\left|a_{22}\right| \ldots \mid a_{2 m}\right]$ keduanya merupakan supermatriks baris yang berbeda. Maka $A_{B}=A_{1} \cup A_{2}$ disebut superbimatriks baris.

Contoh 3.4 Diberikan $\quad A=A_{1} \cup A_{2} \quad$ dimana $\quad A_{1}=\left[\begin{array}{lllllllll}3 & 1 & 0 & 1 & 5 & 0 & 2 & 3 & 1\end{array}\right]$ dan $A_{2}=\left[\begin{array}{ll|llllllll|ll}3 & 0 & 1 & 2 & 2 & 0 & 5 & 3 & 1 & 0 & 1 & 1\end{array}\right] \quad$ maka $A$ suatu superbimatriks baris dimana $A_{1}$ dan $A_{2}$ masing-masing merupakan supermatriks baris. 
Definisi 3.5 [8] Diberikan $A=A_{1} \cup A_{2}$ dengan $A_{1}$ dan $A_{2}$ merupakan supermatriks kolom yang berbeda, dengan : $A_{1}=\left[\begin{array}{c}a_{1}^{1} \\ a_{2}^{1} \\ a_{3}^{1} \\ \hline a_{4}^{1} \\ \vdots \\ a_{m}^{1}\end{array}\right]$ dan $A_{2}=\left[\begin{array}{c}a_{1}^{2} \\ a_{2}^{2} \\ a_{3}^{2} \\ a_{4}^{2} \\ \vdots \\ a_{n}^{2}\end{array}\right]$. Jadi A merupakan superbimatriks superbimatriks kolom.

Contoh 3.6 Diberikan:

$A_{1}=\left[\begin{array}{c}3 \\ 0 \\ 2 \\ 1 \\ 10 \\ -1 \\ 5 \\ 4\end{array}\right]$ dan $A_{2}=\left[\begin{array}{l}1 \\ 2 \\ 3 \\ 4 \\ 5 \\ 6 \\ 7\end{array}\right]$ Maka $A=A_{1} \cup A_{2}$ itu superbimatriks kolom , dimana $A_{1}$ dan $A_{2}$ adalah masingmasing merupakan supermatriks kolom.

Berikut ini diberikan pengertian superbimatriks persegi yang merupakan perpaduan dari dua supermatriks persegi dan juga pengertian superbimatriks persegi panjang yang merupakan perpaduan dua supermatriks persegi panjang.

Definisi 3.7 [8] Diberikan $A=A_{1} \cup A_{2}$. Jika $A_{1}$ dan $A_{2}$ merupakan supermatriks persegi berukuran $m \times$ $m$ yang sama maka $A=A_{1} \cup A_{2}$ merupakan superbimatriks persegi. Selanjutnya jika $A_{1}$ itu supermatriks persegi berukuran $m \times m$ dan $A_{2}$ itu supermatriks persegi $n \times n$ dengan $(m \neq n)$, maka $A=A_{1} \cup A_{2}$ disebut superbimatriks persegi campuran.

Contoh 3.8 Diberikan $A=A_{1} \cup A_{2}, B=B_{1} \cup B_{2}$ dimana

$$
A_{1}=\left[\begin{array}{ll|ll}
1 & 4 & 0 & 2 \\
3 & 7 & 1 & 5 \\
\hline 4 & 6 & 3 & 1 \\
7 & 2 & 4 & 5
\end{array}\right], A_{2}=\left[\begin{array}{lll|l}
3 & 1 & 0 & 2 \\
1 & 0 & 1 & 1 \\
2 & 1 & 0 & 0 \\
\hline 5 & 1 & 1 & 2
\end{array}\right], B_{1}=\left[\begin{array}{ll|ll}
2 & 5 & 7 & 3 \\
1 & 3 & 0 & 2 \\
\hline 4 & 1 & 9 & 7 \\
6 & 2 & 4 & 6
\end{array}\right] \quad B_{2}=\left[\begin{array}{lll|ll}
1 & 3 & 0 & 4 & 3 \\
2 & 6 & 3 & 2 & 2 \\
0 & 7 & 7 & 5 & 1 \\
\hline 4 & 3 & 9 & 7 & 5 \\
6 & 4 & 1 & 9 & 6
\end{array}\right]
$$

$A_{1}, \quad A_{2}$ adalah supermatriks persegi dengan orde yang sama sehingga $A=A_{1} \cup A_{2}$ merupakan superbimatriks persegi sedangkan $B_{1}, B_{2}$ adalah supermatriks persegi dengan orde yang berbeda sehingga $B=B_{1} \cup B_{2}$ itu merupakan superbimatriks persegi campuran.

Definisi 3.9 [8] Diberikan $A=A_{1} \cup A_{2}$, jika $A_{1}$ dan $A_{2}$ merupakan superbimatriks persegi panjang berukuran $m \times n$ maka $A=A_{1} \cup A_{2}$ merupakan superbimatriks persegi panjang.

Selanjutnya jika $A_{1}$ supermatriks persegi panjang ukuran $m_{1} \times n_{1}$ dan $A_{2}$ supermatriks persegi panjang ukuran $m_{2} \times n_{2}$ dengan $\left(m_{1} \neq m_{2}, n_{1} \neq n_{2}\right)$ maka $A=A_{1} \cup A_{2}$ merupakan superbimatriks persegi panjang campuran. 
Contoh 3.10 Diberikan $A=A_{1} \cup A_{2}$ dan $B=B_{1} \cup B_{2}$ dengan :

$$
\begin{aligned}
& A_{1}=\left[\begin{array}{llll|ll}
3 & 1 & 2 & 3 & 5 & 0 \\
1 & 0 & 2 & 1 & 2 & 1 \\
\hline 1 & 0 & 1 & 0 & 1 & 0 \\
2 & 1 & 1 & 1 & 0 & 1
\end{array}\right], \quad A_{2}=\left[\begin{array}{llll|ll}
1 & 1 & 1 & 0 & 0 & 0 \\
1 & 0 & 0 & 1 & 0 & 1 \\
2 & 5 & 0 & 0 & 1 & 0 \\
\hline 3 & 1 & 2 & 2 & 1 & 0
\end{array}\right], B_{1}=\left[\begin{array}{lll|lll}
1 & 0 & 4 & 7 & 1 & 3 \\
3 & 2 & 3 & 9 & 5 & 3 \\
\hline 7 & 4 & 5 & 0 & 7 & 4 \\
8 & 5 & 1 & 3 & 4 & 0
\end{array}\right], \\
& B_{2}=\left[\begin{array}{llll|l}
3 & 5 & 1 & 7 & 0 \\
\hline 1 & 4 & 1 & 6 & 3 \\
5 & 2 & 0 & 1 & 2
\end{array}\right]
\end{aligned}
$$

$A_{1}$ dan $A_{2}$ itu dua supermatriks persegi panjang dengan orde sama yaitu $4 \times 6$, sehingga $A$ dapat disebut superbimatriks persegi panjang. Sedangkan $B_{1}$ dan $B_{2}$ itu dua supermatriks persegi panjang dengan orde berbeda yaitu $4 \times 6$ dan $3 \times 5$. Sehingga $B$ disebut superbimatriks persegi panjang campuran.

Berbeda dengan matriks konvensional, pada supermatriks dua matriks yang berbeda tipe (persegi dan persegi panjang) dapat digabungkan seperti yang dijelaskan dalam definisi berikut.

Definisi 3.11 [8] Diberikan $A=A_{1} \cup A_{2}$ dengan $A_{1}$ dan $A_{2}$ supermatriks. Jika $A_{1}$ supermatriks persegi dan $A_{2}$ supermatriks persegi panjang maka $A=A_{1} \cup A_{2}$ merupakan superbimatriks campuran.

Contoh 3.12 Diberikan $A=A_{1} \cup A_{2}$ dimana :

$$
A_{1}=\left[\begin{array}{ll|lll}
3 & 1 & 0 & 2 & 5 \\
1 & 0 & 1 & 1 & 2 \\
\hline 2 & 1 & 0 & 5 & 1 \\
5 & 1 & 3 & 2 & 1 \\
3 & 2 & 0 & 0 & 3
\end{array}\right] \text { dan } A_{2}=\left[\begin{array}{lll|lll}
4 & 0 & 1 & 1 & 1 & 2 \\
2 & 1 & 0 & 2 & 1 & 5 \\
3 & 1 & 3 & 0 & 1 & 0 \\
\hline 1 & 2 & 5 & 2 & 1 & 0
\end{array}\right]
$$

$A_{1}$ dan $A_{2}$ itu supermatriks dimana $A_{1}$ adalah supermatriks persegi berorde $5 \times 5$ dan $A_{2}$ merupakan supermatriks persegi panjang berorde $4 \times 6$. Jadi, $A=A_{1} \cup A_{2}$ merupakan superbimatriks campuran.

Definisi 3.13 [8] Diberikan $A=A_{1} \cup A_{2}$ dan $B=B_{1} \cup B_{2}$ sebarang dua superbimatriks.

A + B merupakan penjumlahan superbimatriks jika :

1. $A_{1}$ dan $B_{1}$ supermatriks berorde sama dan partisi pada $A_{1}$ dan $B_{1}$ sama atau serupa maka $A_{1}+B_{1}$ terdefinisi ( dapat dijumlahkan ).

2. $A_{2}$ dan $B_{2}$ supermatriks berorde sama dan partisi pada $A_{2}$ dan $B_{2}$ sama atau serupa maka $A_{2}+B_{2}$ terdefinisi ( dapat dijumlahkan ).

Sedemikian sehingga $A=A_{1} \cup A_{2}$ dan $B=B_{1} \cup B_{2}$ jumlahan dari $A$ dan $B$ didefenisikan menjadi :

\section{Contoh 3.14}

$$
\begin{aligned}
A+B & =\left(A_{1} \cup A_{2}\right)+\left(B_{1} \cup B_{2}\right) \\
& =\left(A_{1}+B_{1}\right) \cup\left(A_{2}+B_{2}\right)
\end{aligned}
$$

Diketahui $A=A_{1} \cup A_{2}=\left[\begin{array}{l|l}3 & 2 \\ 1 & 0 \\ 0 & 5\end{array}\right] \cup\left[\begin{array}{lll|lc}1 & 1 & 3 & 0 & 2 \\ 3 & 0 & 5 & 2 & -1 \\ \hline 1 & 1 & 2 & 2 & -5\end{array}\right]$

$A$ adalah gabungan superbimatriks persegi panjang.

$$
\begin{aligned}
A+A & =\left(A_{1} \cup A_{2}\right)+\left(A_{1} \cup A_{2}\right) \\
& =\left(A_{1}+A_{1}\right) \cup\left(A_{2}+A_{2}\right)
\end{aligned}
$$




$$
\begin{aligned}
& =\left[\begin{array}{l|l}
3 & 2 \\
1 & 0 \\
0 & 5
\end{array}\right]+\left[\begin{array}{l|l}
3 & 2 \\
1 & 0 \\
0 & 5
\end{array}\right] \cup\left[\begin{array}{ccc|cc}
1 & 1 & 3 & 0 & 2 \\
3 & 0 & 5 & 2 & -1 \\
\hline 1 & 1 & 2 & 2 & -5
\end{array}\right]+\left[\begin{array}{ccc|cc}
1 & 1 & 3 & 0 & 2 \\
3 & 0 & 5 & 2 & -1 \\
\hline 1 & 1 & 2 & 2 & -5
\end{array}\right] \\
& =\left[\begin{array}{c|c}
6 & 4 \\
2 & 0 \\
0 & 10
\end{array}\right] \cup\left[\begin{array}{ccc|cc}
2 & 2 & 6 & 0 & 4 \\
6 & 0 & 10 & 4 & -2 \\
\hline 2 & 2 & 4 & 4 & -10
\end{array}\right]=2 A_{1} \cup 2 A_{2}
\end{aligned}
$$

Selanjutnya diperoleh $8 A=8 A_{1} \cup 8 A_{2}=\left[\begin{array}{c|c}24 & 16 \\ 8 & 0 \\ 0 & 40\end{array}\right] \cup\left[\begin{array}{ccc|cc}8 & 8 & 24 & 0 & 16 \\ 24 & 0 & 40 & 16 & -8 \\ \hline 8 & 8 & 16 & 16 & -40\end{array}\right]$

Berikut ini diberikan pengertian dari transpos superbimatriks. Diperoleh bahwa transpos superbimatriks adalah transpos dari masing-masing supermatriks yang digabungkan.

Definisi 3.15 [8] Diberikan $A=A_{1} \cup A_{2}$ adalah sebarang superbimatriks. Transpos dari superbimatriks A dinotasikan sebagai $A^{T}$ maka $A^{T}=\left(A_{1} \cup A_{2}\right)^{T}=A_{1}^{T} \cup$ ? $A_{2}{ }^{T}$. Jelas bahwa transpos dari suatu superbimatriks adalah transpos dari masing-masing supermatriks kemudian digabungkan. Jika A suatu gabungan superbimatriks persegi panjang maka disebut $A$ transpos, $A^{T}$ juga adalah gabungan superbimatriks persegi panjang.

\section{Contoh 3.16}

Diberikan $A=A_{1} \cup A_{1}=\left[\begin{array}{llll|lllll}3 & 0 & 1 & 1 \mid-1 & 5 & 2 & 3 & 1\end{array}\right] \cup\left[\begin{array}{lll|lll|llll}1 & 0 & 1|| 5 & 2 & 0 & 1 & 1 & 1 & 0 & 2\end{array}\right]$ Menjadi superbimatriks baris. Transpose dari $A$ dilambangkan dengan $\left(A^{T}\right)$

Jelas bahwa $A^{T}$ merupakan superbimatriks kolom.

$$
A^{T}=\left[\begin{array}{c}
3 \\
0 \\
1 \\
\frac{1}{-1} \\
5 \\
2 \\
3 \\
1
\end{array}\right] \cup\left[\begin{array}{c}
1 \\
0 \\
\frac{1}{5} \\
2 \\
0 \\
\frac{1}{1} \\
1 \\
0 \\
2
\end{array}\right]=A_{1}^{T} \cup A_{2}^{T}
$$

Suatu matriks sederhana dapat digabung dengan suatu supermatriks yang diberikan pada definisi berikut.

Definisi 3.17 [8] Diberikan $A=A_{1} \cup A_{2}$ dimana $A_{1}$ adalah suatu matriks sederhana dan $A_{2}$ adalah suatu supermatriks maka $A$ dapat ditulis $A=A_{1} \cup A_{2}$ merupakan semi superbimatriks.

\section{Contoh 3.18}

Diberikan $A=A_{1} \cup A_{2}=\left[\begin{array}{llll}3 & 1 & 1 & 2 \\ 0 & 5 & 1 & 0\end{array}\right] \cup\left[\begin{array}{ll|ll}3 & 1 & 2 & 0 \\ 5 & 1 & 1 & 1 \\ \hline 2 & 0 & 2 & 6 \\ 1 & 0 & 1 & 5\end{array}\right]$ 
dimana $A_{1}$ itu hanyalah suatu matriks $2 \times 4$ dan $A_{2}$ itu supermatriks persegi, sehingga diperoleh $A$ adalah semi superbimatriks.

Khusus untuk superbimatriks simetri sifat kesimetrian matriks dapat terlihat pada masing-masing sub matriksnya. Untuk lebih jelasnya dapat dilihat pada definisi berikut.

Definisi 3.19 [8] Diberikan $A=A_{1} \cup A_{2}$ suatu superbimatriks. Dapat dikatakan A sebagai suatu superbimatriks simetri jika masing-masing $A_{1}$ dan $A_{2}$ merupakan supermatriks simetris.

Contoh 3.20 Diberikan $A=A_{1} \cup A_{2}$ adalah superbimatriks dimana :

$$
A_{1}=\left[\begin{array}{lll|ll}
0 & 1 & 2 & 3 & 4 \\
1 & 2 & 1 & 2 & 3 \\
2 & 1 & 4 & 2 & 5 \\
\hline 3 & 2 & 2 & 3 & 1 \\
4 & 3 & 5 & 1 & 1
\end{array}\right] \text { dan } A_{2}=\left[\begin{array}{l|lll}
6 & 1 & 2 & 0 \\
\hline 1 & 3 & 1 & 4 \\
2 & 1 & 5 & 1 \\
0 & 4 & 1 & 7
\end{array}\right]
$$

dengan $A_{1}$ dan $A_{2}$ adalah supermatriks simetris, maka $A=A_{1} \cup A_{2}$ adalah superbimatriks simetris.

Definisi 3.20 [8] Diberikan $A=A_{1} \cup A_{2}$ suatu superbimatriks, A dikatakan quasi superbimatriks simetris jika dan hanya jika $A_{1}$ atau $A_{2}$ adalah suatu supermatriks simetris dan $A_{1}$ atau $A_{2}$ adalah supermatriks persegi.

\section{Contoh 3.21}

Diberikan $A=A_{1} \cup A_{2}$ dengan :

$$
A_{1}=\left[\begin{array}{lll|ll}
3 & 2 & 1 & 0 & 5 \\
2 & 1 & 3 & 2 & 1 \\
1 & 3 & 5 & 1 & 2 \\
\hline 0 & 2 & 1 & 4 & 2 \\
5 & 1 & 2 & 3 & 3
\end{array}\right] \text { dan } A_{2}=\left[\begin{array}{ll|ll}
4 & 1 & 2 & 3 \\
2 & 0 & 3 & 4 \\
\hline 2 & 4 & 4 & 1 \\
1 & 5 & 1 & 2
\end{array}\right]
$$

$A$ adalah superbimatriks. Jelas $A_{1}$ adalah supermatriks simetris bisa dilihat bahwa $a_{12}$ dan $a_{21}$ saling transpose dan $A_{2}$ hanya supermatriks persegi. sehingga $A$ adalah quasi superbimatriks simetris.

Definisi 3.22 [8] Diberikan $A=A_{1} \cup A_{2}$ suatu semi superbimatriks. Jika $A_{1}$ atau $A_{2}$ adalah matriks simetris dan $A_{1}$ atau $A_{2}$ adalah suatu supermatriks simetris maka untuk semua A disebut semi superbimatriks simetris.

\section{Contoh 3.23}

Diberikan $A=A_{1} \cup A_{2}$ dimana;

$$
A_{1}=\left[\begin{array}{ll|lll}
5 & 4 & 1 & 2 & 3 \\
4 & 1 & 2 & 3 & 4 \\
\hline 1 & 2 & 4 & 1 & 2 \\
2 & 3 & 1 & 3 & 1 \\
3 & 4 & 2 & 1 & 2
\end{array}\right] \text { dan } A_{2}=\left[\begin{array}{llll}
0 & 1 & 0 & 1 \\
1 & 4 & 3 & 1 \\
0 & 3 & 2 & 1 \\
1 & 1 & 1 & 5
\end{array}\right]
$$

$A$ adalah semi superbimatriks simetris dimana $A_{1}$ adalah supermatriks simetris dan $A_{2}$ adalah matriks simetris.

Definisi 3.24 [8] Diberikan $A=A_{1} \cup A_{2}$ menjadi semi superbimatriks. Jika hanya satu dari $A_{1}$ atau $A_{2}$ adalah matriks simetris (supermatriks simetris) maka A disebut quasi semi superbimatriks simetris 


\section{Contoh 3.25}

Diberikan $A=A_{1} \cup A_{2}$ menjadi semi superbimatriks dimana ;

$$
A_{1}=\left[\begin{array}{lllll}
2 & 1 & 3 & 0 & 5 \\
1 & 5 & 1 & 6 & 2 \\
3 & 1 & 7 & 1 & 2 \\
0 & 6 & 1 & 3 & 1 \\
5 & 2 & 2 & 1 & 4
\end{array}\right] \text { dan } A_{2}=\left[\begin{array}{lll|lll}
3 & 1 & 2 & 5 & 6 & 7 \\
1 & 2 & 3 & 4 & 5 & 6 \\
\hline 2 & 3 & 4 & 5 & 6 & 1 \\
3 & 4 & 5 & 6 & 1 & 2 \\
4 & 5 & 6 & 1 & 2 & 3 \\
5 & 6 & 1 & 2 & 3 & 4
\end{array}\right]
$$

$A$ adalah quasi semi superbimatriks simetris.

Definisi 3.26 [8] Diberikan $A=A_{1} \cup A_{2}$ merupakan superbimatriks segiempat beraturan berukuran $m$ $\times n$ dengan $m<n$. jika kedua $A_{1}$ dan $A_{2}$ hanya partisi pada bagian antara kolom misalnya pada bagian yang vertikal, maka A disebut superbivektor baris.

\section{Contoh 3.27}

Diberikan $A=A_{1} \cup A_{2}$ adalah superbimatriks persegi panjang beraturan dimana ;

$$
A_{1}=\left[\begin{array}{lll|ll|llll}
3 & 0 & 1 & 2 & 1 & 3 & 3 & 2 & 1 \\
1 & 1 & 1 & 3 & 1 & 0 & 1 & 1 & 0 \\
2 & 1 & 1 & 4 & 1 & 0 & 0 & 1 & 0
\end{array}\right] \text { dan } A_{2}=\left[\begin{array}{ll|lll|l|llll}
3 & 1 & 5 & 1 & 0 & 1 & 1 & 1 & 1 & 0 \\
1 & 1 & 7 & 2 & 1 & 2 & 0 & 0 & 1 & 1 \\
0 & 0 & 8 & 3 & 2 & 3 & 2 & 5 & 7 & 8 \\
2 & 1 & 9 & 4 & 3 & 4 & 1 & 2 & 3 & 4
\end{array}\right]
$$

Jadi $A$ menjadi superbivektor baris. Jelas karena partisi dari matriks hanya dengan garis vertikal yaitu antara kolom dan partisinya tidak ada antara baris

Definisi 3.28 [8] Diberikan $A=A_{1} \cup A_{2}$ suatu superbivektor kolom dan $B=B_{1} \cup B_{2}$ suatu superbivektor baris. Untuk menentukan hasil perkalian BA, terlebih dahulu BA dapat didefenisikan jika memenuhi kondisi berikut :

Jika $A=A_{1} \cup A_{2}$ dan $B=B_{1} \cup B_{2}$ dengan;

$$
\begin{aligned}
& A_{1}=\left[\begin{array}{c}
\frac{A_{1}^{1}}{\vdots} \\
\frac{A_{m 1}^{1}}{1}
\end{array}\right] \text { dan } A_{2}=\left[\begin{array}{c}
\frac{A_{1}^{2}}{\vdots} \\
\frac{A_{m 2}^{2}}{2}
\end{array}\right] \\
& B_{1}=\left[\begin{array}{l|l|l}
B_{1}^{1} & \cdots & B_{m 1}^{1}
\end{array}\right] \text { dan } B_{2}=\left[\begin{array}{l|l|l}
B_{1}^{2} & \cdots & B_{m 2}^{2}
\end{array}\right]
\end{aligned}
$$

Maka ;

$$
B A=\left(B_{1} \cup B_{2}\right)\left(A_{1} \cup A_{2}\right)=B_{1} A_{1} \cup B_{2} A_{2}
$$

$B_{1} A_{1}$ dan $B_{2} A_{2}$ adalah perkalian supervektor yang didefenisikan jika dan hanya jika dalam setiap kolom dari $B_{i}^{1}, l \leq i \leq m_{1}$ sama dengan jumlah dalam setiap baris dari $A_{j}^{1}, 1 \leq j \leq m_{1}$ dan jumlah dalam setiap kolom dari $B_{i}^{2}, 1 \leq \mathrm{i} \leq \mathrm{m}_{2}$ sama dengan jika dan hanya jika dalam setiap baris dari $A_{j}^{2}, 1 \leq \mathrm{j} \leq \mathrm{m}_{2}$.

$$
\begin{aligned}
B A & =B_{1} A_{1} \cup B_{2} A_{2} \\
& =\left[B_{1}^{1}|\ldots| B_{m 1}^{1}\right]\left[\frac{A_{1}^{1}}{\frac{\vdots}{A_{m 1}^{1}}}\right] \cup\left[B_{1}^{2}|\cdots| B_{m 2}^{2}\right]\left[\begin{array}{c}
\frac{A_{1}^{2}}{\vdots} \\
\frac{A_{m 2}^{2}}{2}
\end{array}\right] \\
& =\left\{B_{1}^{1} A_{1}^{1}+\cdots+B_{m 1}^{1} A_{m 1}^{1}\right\} \cup\left\{B_{1}^{2} A_{1}^{2}+\cdots+B_{m 2}^{2} A_{m 2}^{2}\right\} \\
& =C \cup D
\end{aligned}
$$


Teorema 3.29 Diberikan $A=A_{1} \cup A_{2}$ adalah superbivektor kolom. Sehingga $A A^{T}$ itu merupakan superbimatriks yang simetris.

\section{Bukti :}

Ambil sebarang dua supervektor kolom seperti berikut :

$$
A=\left[\begin{array}{c}
\frac{A_{1}^{1}}{A_{2}^{1}} \\
\hline \vdots \\
\hline A_{n}^{1}
\end{array}\right] \cup\left[\begin{array}{c}
\frac{A_{1}^{2}}{A_{2}^{2}} \\
\vdots \vdots \\
\overline{A_{n}^{2}}
\end{array}\right]=A_{1} \cup A_{2}
$$

Akan ditunjukan bahwa $A A^{T}$ merupakan superbimatriks simetris.

Berikut ini adalah superbivektor baris (transpose dari supervektor kolom diatas) ;

$$
\begin{aligned}
A^{T} & =\left(A_{1} \cup A_{2}\right)^{T} \\
& =A_{1}^{T} \cup A_{2}^{T} \\
& =\left[A_{1}^{1}\left|A_{2}^{1}\right| \cdots \mid A_{n 1}^{1}\right] \cup\left[A_{1}^{2}\left|A_{2}^{2}\right| \cdots \mid A_{n 2}^{2}\right]
\end{aligned}
$$

Sehingga ;

$$
\begin{aligned}
& A A^{T}=\left(A_{1} \cup A_{2}\right)\left(A_{1} \cup A_{2}\right)^{T} \\
& =\left(A_{1} \cup A_{2}\right)\left(A_{1}^{T} \cup A_{2}^{T}\right) \\
& =A_{1} A_{1}^{T} \cup A_{2} A_{2}^{T} \\
& =\left[\begin{array}{c}
\frac{A_{1}^{1}}{A_{2}^{1}} \\
\vdots \\
\hline A_{n 1}^{1}
\end{array}\right]\left[\begin{array}{lllll|l|l}
A_{1}^{1 T} & \mid A_{2}^{1 T} & A_{3}^{1 T} & \cdots & A_{n 1}^{1 T}
\end{array}\right] \cup\left[\begin{array}{c}
\frac{A_{2}^{1}}{A_{2}^{2}} \\
\frac{\vdots}{A_{n 2}^{2}}
\end{array}\right]\left[\begin{array}{ll|l|l|l|l}
A_{1}^{2 T} & A_{2}^{2 T} & A_{3}^{2 T} & \ldots & A_{n 2}^{2 T}
\end{array}\right] \\
& =\left[\begin{array}{c|c|c|c}
A_{1}^{1} A_{1}^{1 T} & A_{1}^{1} A_{2}^{1 T} & \cdots & A_{1}^{1} A_{n 1}^{1 T} \\
\hline A_{2}^{1} A_{1}^{1 T} & A_{2}^{1} A_{2}^{1 T} & \cdots & A_{2}^{1} A_{n 1}^{1 T} \\
\hline \vdots & \vdots & \ddots & \vdots \\
\hline A_{n 1}^{1} A_{1}^{1 T} & A_{n 1}^{1} A_{2}^{1 T} & \cdots & A_{n 1}^{1} A_{n 1}^{1 T}
\end{array}\right] \cup\left[\begin{array}{c|c|c|c}
A_{1}^{2} A_{1}^{2 T} & A_{1}^{21} A_{2}^{2 T} & \cdots & A_{1}^{2} A_{n 2}^{2 T} \\
\hline A_{2}^{2} A_{1}^{2 T} & A_{2}^{2} A_{2}^{2 T} & \cdots & A_{2}^{2} A_{n 2}^{2 T} \\
\hline \vdots & \vdots & \ddots & \vdots \\
\hline A_{n 2}^{2} A_{1}^{2 T} & A_{n 2}^{2} A_{2}^{2 T} & \cdots & A_{n 2}^{2} A_{n 2}^{2 T}
\end{array}\right]
\end{aligned}
$$

Dari hasil di jelas dapat dilihat bahwa $\left(A_{1}^{1} A_{i}^{1 T}\right)^{T}=A_{i}^{1} A_{1}^{1 T} ; i=1,2, \ldots, \mathrm{n}_{1}$. Juga $\left(A_{j}^{2} A_{k}^{2 T}\right)^{T}=A_{k}^{1} A_{j}^{1 T}$ ( memenuhi sifat matriks simetri) $, 1 \leq k, j \leq n_{2}$ sehingga $\left(A A^{T}\right)^{T}=A A^{T}$. maka terbukti $A A^{T}$ itu merupakan superbimatriks simetri.

\section{Contoh 3.30}

Ambil sebarang dua supervektor kolom seperti berikut :

$$
\begin{aligned}
& A_{1}=\left[\begin{array}{l}
\frac{a}{b} \\
c \\
d
\end{array}\right] \text { dan } A_{2}=\left[\begin{array}{c}
e \\
\frac{f}{g} \\
h
\end{array}\right], A=A_{1} \cup A_{2} \\
& A^{T}=\left(A_{1} \cup A_{2}\right)^{T} \\
&=A_{1}^{T} \cup A_{2}^{T} \\
&=\left[\begin{array}{lll}
a \mid b & c & d
\end{array}\right] \cup\left[\begin{array}{lll}
e & f \mid g & h
\end{array}\right]
\end{aligned}
$$

Sehingga: 


$$
\begin{aligned}
A A^{T} & =\left(A_{1} \cup A_{2}\right)\left(A_{1} \cup A_{2}\right)^{T} \\
& =\left(A_{1} \cup A_{2}\right)\left(A_{1}^{T} \cup A_{2}^{T}\right) \\
& =A_{1} A_{1}^{T} \cup A_{2} A_{2}^{T} \\
& =\left[\begin{array}{c}
\frac{a}{b} \\
c \\
d
\end{array}\right]\left[\begin{array}{llll}
a & b & c & d
\end{array}\right] \cup\left[\begin{array}{c}
e \\
\frac{f}{g} \\
h
\end{array}\right]\left[\begin{array}{ll|ll}
e & f & g & h
\end{array}\right] \\
& =\left[\begin{array}{l|lll}
a a & a b & a c & a d \\
\hline b a & b b & b c & b d \\
c a & c b & c c & c d \\
d a & d b & d c & d a
\end{array}\right] \cup\left[\begin{array}{ll|ll}
e e & e f & e g & e h \\
f e & f f & f g & f h \\
\hline g e & g f & g g & g h \\
h e & h f & h g & h h
\end{array}\right]
\end{aligned}
$$

Dari hasil di atas dapat dilihat bahwa hasil kali dari dua supervector dengan asumsi $A A^{T}$ itu merupakan superbimatriks simetris (dilihat dari $a_{21}$ yang merupakan transpose atau pencerminan dari $a_{21}$ ).

\section{Kesimpulan}

Dari hasil dan pembahasan yang telah diuraikan sebelumnya, dapat disimpulkan bahwa superbimatriks merupakan perpaduan atau kumpulan dari supermatriks yang berbeda ukuran dimana supermatriks merupakan matriks sederhana yang dipartisi atau matriks baru yang disusun oleh matriks matriks sederhana yang dikenal dengan aturan $1 \leq \mathrm{i}, \mathrm{j} \leq 2$. Pada dasarnya struktur dari matriks biasa dan superbimatriks sama namun yang membedakannya adalah elemennya dimana elemen dari matriks biasa adalah skalar-skalar sedangkan elemen dari superbimatriks adalah matriks-matriks yang telah dipartisi atau juga skalar. Diperoleh beberapa bentuk superbimatriks seperti superbimatriks campuran, semi superbimatriks, dll serta sifat yang menyatakan bahwa jika $A=A_{1} \cup A_{2}$ yang merupakan superbivektor kolom maka $A A^{T}$ merupakan superbimatriks simetri.

\section{Daftar Pustaka}

[1] Anton, Howard. (2000). Dasar-Dasar Aljabar Linear: Jilid 1.

[2] Deligne, P. and Morgan, J.W. (1999) Notes on supersymmetry following Bernstein. Quantum fields and strings; a course for mathematicians, vol. 1, Amer. Math. Soc.

[3] Frank Ayres, JR., Ph.D (1984). Teori Dan Soal-Soal Matriks.

[4] Horst, P. (1963) Matrix Algebra for Social Scientists, Holt.

[5] Jacob Bill (1995) Linear Functions and Matrix Theory.

[6] Varadarajan, V.S (2004) Supersymmetry for mathematicians; an introduction. Couran Lecture Notes. Courant Lecture Notes Series, New York.

[7] W. B. Vasantha Kandasamy dan Florentin Smarandache. (2009). Bimatriks.

[8] W. B. Vasantha Kandasamy dan Florentin Smarandache. (2009). Superbimatrices and Their Generalization

[9] Yost, S.A 1991. Supermatriks models. Interasional journal of modern physicsa vol, 7, no. 24 (1992). 